\section{The role of DNA amplification and cultural growth in compli- cated acute appendicitis}

\author{
Francesca Tocchioni, 1 Chiara Tani, 1 \\ Laura Bartolini,2 Maria Moriondo,3 \\ Francesco Nieddu,3 Patrizia Pecile,2 \\ Chiara Azzari,3 Antonio Messineo,1 \\ Marco Ghionzoli1 \\ 1Department of Pediatric Surgery, \\ University of Florence and Children's \\ University Hospital A. Meyer; \\ 2Department of Microbiology, Careggi \\ Hospital, Florence, ${ }^{3}$ Department of \\ Clinical Immunology, University of \\ Florence and Children's University \\ Hospital A. Meyer, Italy
}

\section{Abstract}

Bacterial growth of peritoneal fluid specimens obtained during surgical procedures for acute appendicitis may be useful to optimize further antibiotic therapy in complicated cases. DNA amplification represents a fast technique to detect microbial sequences. We aimed to compare the potential of DNA amplification versus traditional bacterial growth culture highlighting advantages and drawbacks in a surgical setting. Peritoneal fluid specimens were collected during surgery from 36 children who underwent appendectomy between May and December 2012. Real-time polymerase chain reaction (RT-PCR) and cultures were performed on each sample. RT-PCR showed an amplification of $16 \mathrm{~S}$ in 18/36 samples, Escherichia coli (in 7 cases), Pseudomonas aeruginosa (3), Fusobacterium necrophorum (3), Adenovirus (2), E.coli (1), Klebsiella pneumoniae (1), Serratia marcescens/Enterobacter cloacae (1). Bacterial growth was instead observed only in four patients (3 E.coli and 1 P.aeruginosa and Bacteroides ovatus). Preoperative C-reactive protein and inflammation degree, the most reliable indicators of bacterial translocation, were elevated as expected. DNA amplification was a quick and useful method to detect pathogens and it was even more valuable in detecting aggressive pathogens such as anaerobes, difficult to preserve in biological cultures; its drawbacks were the lack of biological growths and of antibiograms. In our pilot study RT-PCR and cultures did not influence the way patients were treated.

\section{Introduction}

Obtaining intra-abdominal cultures for complicated appendicitis has been a routine surgical practice for decades. The presence of bacteria within the peritoneal cavity during inflammatory processes was demonstrated at the beginning of the past century and the bacteria involved have been subsequently found, the most common ones being Escherichia coli, followed by Klebsiella pneumoniae, Streptococcus species, Enterococcus species and Pseudomonas aeruginosa.1,2 This led to the adjustment of post-operative empirical antibiotic treatment, ${ }^{3-10}$ although with the advent of broad spectrum antibiotics, routinary microbiological cultures of abdominal fluid specimens lost most of their importance.11,12 Moreover, a specific disadvantage of cultures was that both pathogen identification and antibiotic sensitivity results were often available only after patients discharge. 13 Over the past few years, real-time polymerase chain reaction (RT-PCR) has been introduced in clinical practice: thanks to this method within $6-24$ hours it is possible to detect hardly cultivable, non cultivable or dead microorganism strains with high specificity and sensitivity. ${ }^{14}$ RT-PCR has been employed in several studies with pediatric populations confirming that a prompt detection of either viral or bacterial agent contributes to patient care, which in turn has effect on both hospital stay and antibiotic usage. ${ }^{15-19}$ To date, a couple of studies about the use of RT-PCR to detect pathogens in the peritoneal fluid during acute appendicitis have been carried out without any further conclusion. ${ }^{20,21}$ Taking into account these previous reports, we set a pilot study in order to better understand and compare the potential advantages of DNA amplification versus traditional bacterial growth culture in complicated acute appendicitis, and identify, when possible, those categories of patients, who might benefit from this combined approach.

\section{Materials and Methods}

Between May and December 2012, 36 children consecutively underwent appendectomy for complicated appendicitis, either with localized or diffused peritonitis. The mean age was 12 years (range $3-17$ ); 21 patients were male and 15 were female. Two patients were operated with an open approach whilst 34 were performed using a laparoscopic approach. Peritoneal fluid or pus swabs were collected during surgery: when the procedure was carried out laparoscopically, the liquid was suctioned into a syringe via a small bore Nelaton catheter inserted in a $5 \mathrm{~mm}$ trocar. Otherwise
Correspondence: Marco Ghionzoli, Department of Pediatric Surgery, University of Florence and Children's University Hospital A. Meyer, Florence, Italy.

Tel.: +39.055.5662414. Fax: +39.055.5662400.

E-mail: marco.ghionzoli@unifi.it

Key words: Antibiotics therapy; complicated appendicitis; microbiological culture; pathogens; Real-time-PCR.

Contributions: MG, CT contributed to the design of this study; FT contributed to collect samples and drafted the manuscript; LB, PP performed the microbiological analysis; MM, FN performed the molecular biology analysis; MG critically reviewed the manuscript and supervised the whole study process; CA gave technical support and conceptual advice; AM supervised the whole study process.

Conflict of interest: the authors declare no potential conflict of interest.

Received for publication: 25 February 2016. Revision received: 4 July 2016.

Accepted for publication: 29 July 2016.

This work is licensed under a Creative Commons Attribution NonCommercial 4.0 License (CC BYNC 4.0).

(C) Copyright F. Tocchioni et al., 2016

Licensee PAGEPress, Italy

Pediatric Reports 2016; 8:6487

doi:10.4081/pr.2016.6487

it was collected right after the peritoneal incision. The fluid specimen was split into vials respectively for microbiological cultures and molecular biology analyses. The initial antibiotic plan for complicated appendicitis comprised ceftazidime [35 $\mathrm{mg} / \mathrm{kg}$ total dissolved solids (TDS)], metronidazole (7.5 mg/kg TDS) and gentamicine $(7 \mathrm{mg} / \mathrm{kg}$ 0D, max $240 \mathrm{mg}$ OD). The second line antibiotic plan included meropenem (20 mg/kg TDS), teicoplanin (5 $\mathrm{mg} / \mathrm{kg}$ twice daily) and metronidazole (7.5 $\mathrm{mg} / \mathrm{kg}$ TDS). The second line regimen was established after about 5-7 days, if initial treatment was deemed unsuccessful (i.e. persistent fever, augmented white blood cell (WBC) and/or cAMP receptor protein (CRP), ultrasound scan positive for intra-abdominal collection. We recorded any changes in the therapeutic plan (i.e. antibiotics) after obtaining the reports of molecular and cultural tests or antibiograms. This study was deemed as a quality improvement project therefore ethics review was not sought.

\section{Molecular biology analyses}

Bacterial genomic DNA was extracted from $200 \mu \mathrm{L}$ of biological samples using the QIAmp DNA Easy Blood \& Tissue kit (Qiagen, Venlo, 
Table 1. Real-time polymerase chain reaction primers.

\begin{tabular}{lccc} 
Target & Forward primer & Reverse primer \\
$\begin{array}{l}\text { P. aeruginosa } \\
\text { S. aureus }\end{array}$ & ccggagaccttcagcaacat & gacgccggagttgaggaa & Probe \\
F. necrophorum & gttctatatcaactgtagcttctttatcca & cattaaaggtgtgcaaaagatggt & FAM_atcctggccaagcgcatccg \\
\hline
\end{tabular}

The Netherlands), according to the manufacturer's instructions. RT-PCR for Adenovirus, $E$. coli and $K$. pneumoniae was performed using Eusepscreen (Eurospital, Trieste, Italy) kit according to the manufacturer's instructions. RT-PCR for $P$. aeruginosa, Staphylococcus aureus and Fusobacterium necrophorum was performed using primers and probes described in Table 1. All reactions were performed in triplicates. A negative control (no template) and a positive control for each pathogen were included in every run. DNA was amplified in an ABI 7500 sequence detection system (Applied Biosystems, Foster City, California, USA, brand of ThermoFisher, Waltham, Massachusetts, USA) using the following cycling parameters: $95^{\circ} \mathrm{C}$ for 10 min followed by 45 cycles of a twostage temperature profile of $95^{\circ} \mathrm{C}$ for $15 \mathrm{~s}$ and $60^{\circ} \mathrm{C}$ for 1 min. $16 \mathrm{~S}$ PCR was performed according to standard protocols. ${ }^{22}$

\section{Microbiological analyses}

Clinical specimens for cultural analysis were collected into anaerobic transport vials (Portagerm bioMerieux, Craponne, France) and inoculated onto an array of culture media suitable for detection of fastidious and nonfastidious aerobic bacteria, anaerobes and fungi (Columbia blood agar, chocolate agar, Schaedler CNA agar, Shaedler KKV agar, and sabouraud dextrose agar) after an enrichment step at $35^{\circ} \mathrm{C}$ in thioglycollate broth and nutrient broth. Cultures were carried out at $35^{\circ} \mathrm{C}$ for $48 \mathrm{~h}$ under aerobic (Columbia blood agar and sabouraud dextrose agar), 5\% CO2 enriched (chocolate agar) or anaerobic (Schaedler CNA agar and Shaedler KKV agar) conditions. Identification of microbial isolates and antimicrobial susceptibility testing were carried out by the Vitek2 automated system (bioMérieux, Craponne, France).

\section{Results}

Perioperative blood tests of patients showed a mean WBC of $14.96 \mathrm{k} / \mathrm{uL}$ (range 7.54-26.37 $\mathrm{k} / \mathrm{uL}$ ), the mean neutrophil percentage was $81 \%$ (range of $75-92 \%$ ). The mean CRP value was $10.1 \mathrm{mg} / \mathrm{dL}$ (range $2.3-23.8 \mathrm{mg} / \mathrm{dL}$; cut off

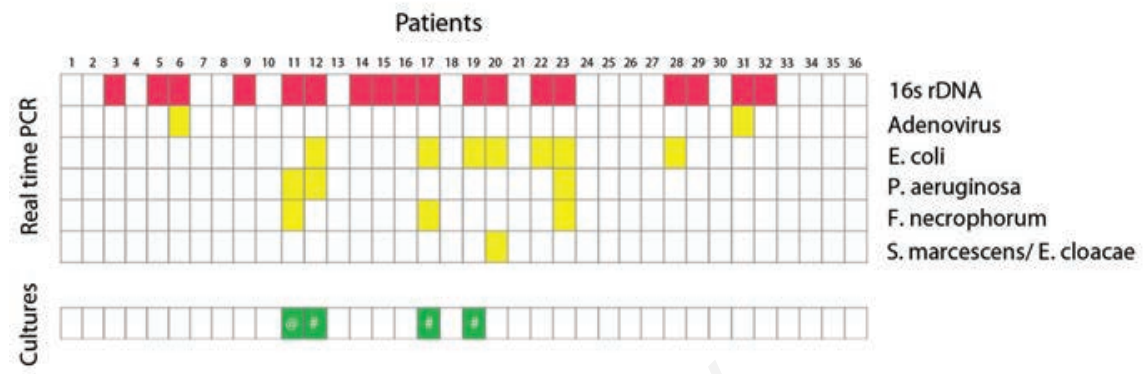

Figure 1. Results of real-time polymerase chain reaction (RT-PCR) analysis and cultures of specimens from 36 patients. Positive results are marked as blank squares. In three cultures (patient $12 ; 17 ; 19)$ grew $E$. coli at (\#), in another one (patient 11) P. aeruginosa and B. ovale (@). Samples from these four patients resulted positive both to RT-PCR and culture.

$<0.2 \mathrm{mg} / \mathrm{dL})$. The mean length of stay was 7 days (range 5-23). We observed only one postoperative infectious complication due to an intra-abdominal collection. The DNA amplification technique on peritoneal fluid demonstrated a nonspecific amplification of $16 \mathrm{~S}$ ribosomial DNA in 18 patients, as reported in Figure 1. Due to the presence of multiple bacteria within the sample we were unable to proceed with gene sequencing in order to identify the bacteria corresponding to the $16 \mathrm{~S}$ ribosomial DNA. In two cases DNA amplification revealed specific sequences of adenoviral DNA, whilst specific sequences from E.coli were retrieved in seven patients and $P$. aeruginosa in three patients. In four samples we identified anaerobia: three $F$. necrophorum and one Serratia marcescens/Enterobacter cloacae. Samples collected from four patients had positive microbiological cultures: in three cultures we observed $E$. coli growth while in another $P$. aeruginosa and Bacteroides ovatus. In these four patients, microorganisms were detected with both methodologies. No therapeutic plan has been changed after obtaining the results of molecular, microbiology and antibiograms cultures. The profile of the patient in which we detected at day 7 an intraabdominal collection showed specific DNA sequences positive to $E$. coli, $P$. aeruginosa and $F$. necrophorum. Cultures were positive to $P$. aeruginosa and $B$. ovatus. Based on clinical evolution, this patient swapped to second line antibiotics on day 8 and was eventually discharged on day 23 .

\section{Discussion}

Acute appendicitis is the most common surgical emergency in children and when complicated with local or diffused peritonitis, it requires an adequate and prolonged antibiotic therapy. Classical microbiological detection based on culture has been kept alive for almost a century being still the core technology of clinical laboratories. ${ }^{23}$ However, microbiological cultures may produce false negatives for several reasons: small sample volume, slow growing bacteria, uncommon phenotypes, previous antibiotic therapy or inadequate conditions of transport and storage. 16,24 The main purpose of obtaining intraoperative samples for microbiological cultures in appendicitis was to identify, whether pathogens resistant to empirical antibiotics were present. Foo and colleagues collected data from more than 600 cases of acute appendicitis, demonstrating that less than 20 cultures grew resistant pathogens. ${ }^{11}$ Similarly, Kenig and colleagues studied more than 300 cases of acute appendicitis, being able to identify five patients in which bacteria were resistant to the empiric antibiotic therapy. ${ }^{12}$ In both studies, the postoperative outcome resulted to be related more to the degree of inflammation rather than the type of pathogens involved in the infection. Therefore, routine intra-operative cultures during appendectomy have shown little value in patient management and outcome: as a result, most cultures today are considered use- 
less and a waste of resources.11,12 Although lacking of antibiotic testing, RT-PCR has demonstrated its usefulness for a prompt DNA detection of both dead and living microorganisms.23,25 The use of DNA amplification to detect pathogens in acute appendicitis has been already reported,20,21 though no reports are available concerning the efficacy of DNA amplification versus microbiological culture. In our study, RT-PCR has demonstrated to be effective to detect bacteria in roughly half of the samples, whereas cultures showed growth in only about $10 \%$ of the samples, demonstrating that RT-PCR was more than four times more sensitive than conventional cultures. Comparative microbiological and molecular biology testing for pathogens has been investigated in the pediatric field for pleural empyema, spontaneous bacterial peritonitis, among other diseases. ${ }^{15-19}$ In pleural empyema, RTPCR played an important role identifying pathogens in those patients with no culture growth, who had followed a previous antibiotic course.15,16 Similar results were available for microbiological diagnosis in spontaneous bacterial peritonitis where RT-PCR increased the efficacy of cultures: RT-PCR detected pathogen in nearly all the patients with positive culture, and RT-PCR resulted positive in half of the patients with negative cultures. ${ }^{17}$ Although molecular diagnosis cannot be considered as a replacement method in the clinical setting, there is an increasing awareness of the benefits, which may derive from the combined use of molecular analyses and conventional microbiology to optimize the research of pathogens.16,24,25 Concerning our pilot study, RT-PCR has been undoubtedly a valuable tool to detect aggressive pathogens such as anaerobia, which are usually difficult to preserve alive in biological cultures. Almost all the operations in this series were performed by means of laparoscopy, a procedure that requires intraabdominal insufflation of carbon dioxide. Interestingly enough, this aspect could have been responsible for creating an acceptable environment for the anaerobia collected in the sample.26-28 From a clinical standpoint, the information obtained from cultures and RTPCR had a minimal influence in therapeutical plan: bacteria were detected with both techniques in only about $10 \%$ of the patients, empirical antibiotic treatment in our series was deemed adequate and antibiotics were not swapped after obtaining the results from either RT-PCR or cultures. Although half of the samples examined resulted positive to $16 \mathrm{~S}$, we were unable to proceed to gene sequencing because of the presence of multiple flora within the peritoneal samples. A practical way to circumvent this issue would have been to have increased RT-PCR panels by adding several primers for comprehensive bacteria identification, although this would have increased costs.

\section{Conclusions}

We can conclude that a routinely use of either methodology has been proven worthless because the results obtained with RT-PCR did not have any influence in the therapeutic plan. The empirical antibiotic therapy (first and second line) for treating complicated acute appendicitis has been demonstrated adequate to face infectious complications in our series. ${ }^{11}$ Nonetheless, our results confirm the value and usefulness of DNA amplification to detect pathogens in fluid specimens, especially anaerobia, resistant or dead germs, which compensate for the lack of sensitivity of the culture, particularly for children receiving antibiotic treatment. We prove that molecular analysis identifies pathogens in about half of examined specimens, while conventional microbiology results positive in about only $10 \%$ of cases. Under this perspective, molecular biology could have a significant value when employed in epidemiological studies as previously demonstrated with growth cultures. $9,10,21$ A combined use of RT-PCR and conventional culture which provides antibiograms on peritoneal fluid specimens in complicated acute appendicitis could be beneficial only for selected cases such as younger children and patients with comorbidities which are burdened by a higher risk of infectious complications.

\section{References}

1 Altemeier WA. The bacterial flora of acute perforated appendicitis with peritonitis: a bacteriologic study based upon one hundred cases. Ann Surg 1938;107:517-28.

2 Lorber B, Swenson RM. The bacteriology of intra-abdominal infections. Surg Clin North Am 1975;55:1349-54.

3 Stone HH, Kolb LD, Geheber CE. Incidence and significance of intraperitoneal anaerobic bacteria. Ann Surg 1975;181:705-15.

4 Roberts JP. Quantitative bacterial flora of acute appendicitis. Arch Dis Child 1988;63: $536-40$.

5 Bennion RS, Baron EJ, Thompson JE Jr, et al. The bacteriology of gangrenous and perforated appendicitis-revisited. Ann Surg 1990;211:165-71.

6 Rautio M, Saxen H, Siitonen A, et al. Bacteriology of histopathologically defined appendicitis in children. Pediatr Infect Dis J 2000;19:1078-83.

7 Holder TM, Ashcraft KW. Pediatric surgery. Saunders ed.: Philadelphia; 1980.

8 Katzoli P, Sakellaris G, Ergazaki M, et al. Detection of herpes viruses in children with acute appendicitis. J Clin Virol 2009;44:282-6.
9 Chen CY, Chen YC, Pu HN, et al. Bacteriology of acute appendicitis and its implication for the use of prophylactic antibiotics. Surg Infect (Larchmt) 2012;13:383-90.

10 Guillet-Caruba C, Cheikhelard A, Guillet M, et al. Bacteriologic epidemiology and empirical treatment of pediatric complicated appendicitis. Diagn Microbiol Infect Dis 2011;69:376-81.

11 Foo FJ, Beckingham IJ, Ahmed I. Intraoperative culture swabs in acute appendicitis: a waste of resources. Surgeon 2008;6:278-81.

12 Kenig J, Richter P. The need for culture swabs in laparoscopically treated appendicitis. Wideochir Inne Tech Malo Inwazyjne 2013;8:310-4.

13 Moawad MR, Dasmohapatra S, Justin T, Keeling N. Value of intraoperative abdominal cavity culture in appendicectomy: a retrospective study. Int $\mathrm{J}$ Clin Pract 2006;60:1588-90.

14 Espy MJ, Uhl JR, Sloan LM, et al. Real-time PCR in clinical microbiology: applications for routine laboratory testing. Clin Microbiol Rev 2006;19:165-256.

15 Blaschke AJ, Heyrend C, Byington CL, et al. Molecular analysis improves pathogen identification and epidemiologic study of pediatric parapneumonic empyema. Pediatr Infect Dis J 2011;30:289-94.

16 Le Monnier A, Carbonnelle E, Zahar JR, et al. Microbiological diagnosis of empyema in children: comparative evaluations by culture, polymerase chain reaction, and pneumococcal antigen detection in pleural fluids. Clin Infect Dis 2006;42:1135-40.

17 Soriano G, Esparcia 0, Montemayor M, et al. Bacterial DNA in the diagnosis of spontaneous bacterial peritonitis. Aliment Pharmacol Ther 2011;33:275-84.

18 Azzari C, Moriondo M, Indolfi G, et al. Realtime PCR is more sensitive than multiplex PCR for diagnosis and serotyping in children with culture negative pneumococcal invasive disease. PLoS One 2010;5:e9282.

19 Wishaupt J0, Russcher A, Smeets LC, et al. Clinical impact of RT-PCR for pediatric acute respiratory infections: a controlled clinical trial. Pediatrics 2011;128:e111320.

20 Pogorelic Z, Biocic M, Juric I, et al. Acute appendicitis as a complication of varicella. Acta Medica (Hradec Kralove) 2012;55:150-2.

21 Guinane CM, Tadrous A, Fouhy F, et al. Microbial composition of human appendices from patients following appendectomy. MBio 2013;4.pii:e00366-12.

22 Lu JJ, Perng CL, Lee SY, Wan CC. Use of PCR with universal primers and restriction endonuclease digestions for detection 
and identification of common bacterial pathogens in cerebrospinal fluid. J Clin Microbiol 2000;38:2076-80.

23 van Belkum A. Molecular diagnostics in medical microbiology: yesterday, today and tomorrow. Curr Opin Pharmacol 2003;3:497-501.

$24 \mathrm{Kim} \mathrm{SH}$, Jeong $\mathrm{HS}$, Kim $\mathrm{YH}$, et al. Evaluation of DNA extraction methods and their clinical application for direct detection of causative bacteria in continuous ambulatory peritoneal dialysis culture flu- ids from patients with peritonitis by using broad-range PCR. Ann Lab Med 2012;32:119-25.

25 Weile J, Knabbe C. Current applications and future trends of molecular diagnostics in clinical bacteriology. Anal Bioanal Chem 2009;394:731-42.

26 Sare M, Yesilada 0, Gurel M, et al. Effects of $\mathrm{CO} 2$ insufflation on bacterial growth in rats with Escherichia coli-induced experimental peritonitis. Surg Laparosc Endosc 1997;7:38-41.
27 Sare M, Demirkiran AE, Alibey E, Durmaz B. Effect of abdominal insufflation on bacterial growth in experimental peritonitis. $\mathrm{J}$ Laparoendosc Adv Surg Tech A 2001;11:285-9.

28 Sare M, Demirkiran AE, Tastekin N, Durmaz B. Effects of laparoscopic models on anaerobic bacterial growth with bacteroides fragilis in experimentally induced peritonitis. J Laparoendosc Adv Surg Tech A 2003;13:175-9. 